\title{
RUANG LINGKUP HUKUM ISLAM
}

\author{
Muhammad Kurniawan Budi Wibowo \\ Institut Islam Mamba'ul 'Ulum Surakarta \\ e-mail: $\underline{\text { mkbwsolo1@yahoo.com }}$
}

\begin{abstract}
Abstrack: This study describes Islamic law and its scope. This research uses a qualitative approach with descriptive research type. Data analysis using descriptive analysis. The process is carried out since the data, so that when in the field, researchers have started the data analysis process until the end of the research. This research concludes that etymologically Islamic law is all kinds of provisions or provisions regarding something in which the provisions have been regulated and stipulated by Islam. The scope of Islamic law is divided into two, namely 1) law relating to matters of worship, and 2) law relating to social matters. In addition, there is a study of the principles of Islamic law. The value of the divine value is implemented into a number of basic principles or as a more concrete one in a number of fields of Islamic law. As well as the objectives of Islamic law are not limited in terms of material alone, but far in the future pay attention to all aspects, material, immaterial, individuals, society, and humanity in general. The last one regarding the sources of Islamic law. The sources of Islamic law are Al-Qur'an, Al- haditht, and Ar-ra'yu (reasoning).
\end{abstract}

Keywords: Islamic Law, Scope

\section{PENDAHULUAN}

Istilah hukum Islam sendiri terdiri dari dua suku kata yang berasal dari bahasa Arab yakni kata hukum dan kata Islam. Kata hukum berarti ketentuan dan ketetapan. Sedangkan kata Islam terdapat dalam Al-Qur'an, yakni kata benda yang berasal dari kata kerja "salima" selanjutnya menjadi Islam yang berarti kedamaian, kesejahteraan, keselamatan, atau penyerahan (diri) dan kepatuhan. ${ }^{1}$ Sehingga dapat ditarik kesimpulan bahwa hukum Islam secara etimologis adalah segala macam ketentuan atau ketetapan mengenai sesuatu hal di mana ketentuan itu telah diatur dan ditetapkan oleh Agama Islam.

Dari segi istilah, hukum menurut ajaran Islam antara lain dikemukakan oleh Abdurraf, hukum adalah peraturan-peraturan yang terdiri dari ketentuan-ketentuan, suruhan dan larangan, yang menimbulkan kewajiban dan atau hak. ${ }^{2}$ Pada kesempatan ini, kami mencoba untuk menjelaskan tentang ruang lingkup hukum Islam, prinsip-prinsip hukum Islam, Tujuan Hukum Islam dan Prinsip-prinsip Hukum Islam.

\section{METODE PENELITIAN}

Penelitian ini menggunakan pendekatan kualitatif dengan jenis penelitian deskriptif. Analisis data penelitian ini menggunakan analisis deskriptif. Prosesnya dilakukan semenjak pengumpulan data, sehingga saat dilapangan, peneliti sudah mulai melakukan proses analisis data hingga penelitian berakhir. Artinya, hal-hal yang terkait dengan Hukum Islam dan ruang lingkupnya dianalisis secara mendalam.

\footnotetext{
${ }^{1}$ Mohammad Daud Ali, 2007, Hukum Islam, Pengantar Ilmu Hukum dan Tata Hukum Islam di Indonesia, PT. Rajagrafindo, Jakarta, hlm. 21.

${ }^{2}$ M. Arfin Hamid, 2008, Hukum Islam Prespektif Keindonesiaan: Sebuah Pengantar dalam Memahami Realitas Hukum Islam di Indonesia, Fakultas Hukum Universitas Hasanuddin, hlm.13
} 


\section{PEMBAHASAN}

\section{Ruang Lingkup Hukum Islam}

Ruang lingkup hukum Islam diklasifikasi ke dalam dua kelompok besar, yaitu: ${ }^{3}$ 1) hukum yang berkaitan dengan persoalan ibadah, dan 2) hukum yang berkaitan dengan persoalan kemasyarakatan. Hal ini akan diuraikan sebagai berikut.

1. Hukum ibadah adalah hukum yang mengatur hubungan manusia dengan Tuhannya, yaitu iman, shalat, zakat, puasa, dan haji.

2. Hukum kemasyarakatan, yaitu hukum yang mengatur hubungan manusia dengan sesamanya yang memuat: muamalah, munakahat, dan ukubat.

a. Muamalah mengatur tentang harta benda (hak, obligasi, kontrak, seperti jual beli, sewa menyewa, pembelian, pinjaman, titipan, pengalihan utang, syarikat dagang, dan lain-lain).

b. Munakahat, yaitu hukum yang mengatur tentang perkawinan dan perceraian serta akibatnya seperti iddah, nasab, nafkah, hak curatele, waris, dan lain-lain. Hukum dimaksud biasa disebut hukum keluarga dalam bahasa Arab disebut Al-Ahwal AlSyakhsiyah. Cakupan hukum dimaksud biasa disebut hukum perdata.

c. Ukubat atau Jinayat, yaitu hukum yang mengatur tentang pidana seperti mencuri, berzina, mabuk, menuduh berzina, pembunuhan serta akibat-akibatnya. Selain bagianbagian tersebut, ada bagian lain yaitu

1) mukhasamat,

2) siyar,

3) ahkam as-sulthaniyah.

Hal ini akan dijelaskan sebagai berikut:

Mukhasamat, yaiu hukum yang mengatur tentang peradilan: pengaduan dan pembuktian, yaitu hal-hal yang berkaitan dengan hukum acara perdata dan hukum acara pidana

1) Siyar, yaitu hukum yang mengatur mengenai urusan jihad dan/atau perang, harta rampasan perang, perdamaian, perhubungan dengan Agama lain, dan negara lain.

2) Ahkam As-Sulthaniyah, yaitu hukum yang membicarakan persoalan hubungan dengan kepala negara, kementerian, gubernur, tentara, dan pajak.

Kalau bagian-bagian hukum Islam itu disusun menurut sistematika hukum eks Barat yang membedakan antara hukum perdata dengan hukum publik seperti yang diuraikan pada pembagian hukum menurut daya kerjanya, maka susunan hukum muamalah dalam arti luas adalah sebagai berikut: ${ }^{4}$

Hukum perdata (Islam) adalah (1) munakahat (mengatur segala sesuatu yang berhubungan dengan perkawinan, perceraian, serta akibat-akibatnya); (2) wirasah (mengatur segala masalah yang berhubungan dengan pewaris, ahli waris, harta peninggalan, serta pembagian warisan). Hukum waris ini sering disebut hukum faraid; (3) muamalah dalam arti khusus mengatur masalah kebendaan, hak-hak atas`benda, tata hubungan manusia dengan soal jual beli, sewa menyewa, perserikatan, dan sebagainya. Hukum publik (Islam) adalah (4)

${ }^{3}$ Zainuddin Ali, 2006, Hukum Islam, Pengantar Ilmu Hukum Islam di Indonesia, Jakarta, Sinar Grafika, hlm. 6-7

${ }^{4}$ Mohamad Daud Ali, Op.Cit, hlm. 57-58 
jinayat (memuat aturan-aturan mengenai perbuatan yang diancam hukuman pidana); (5) alahkam as-sulthaniyah (membicarakan soal-soal yang berhubungan dengan kepala negara, pemerintahan, tentara, pajak, dan sebagainya); (6) siyar (mengatur urusan perang dan damai, tata hubungan dengan pemeluk Agama, dan negara lain); (7) mukhamasat (mengatur soal peradilan, kehakiman, dan tata hukum acara).

Pada umumnya hukum Islam dibagi atas dua macam oleh para fuqaha: ${ }^{5}$

1. Yang bersifat perintah, larangan, atau pilihan. Golongan ini bernama Hukum Takliefy yang terbagi atas lima yaitu wajib, sunat, mubah, makruh, dan haram.

2. Yang bersifat menunjukkan keadaan-keadaan tertentu yang dikualifikasi sebagai sebab atau syarat atau halangan bagi berlakunya hukum. Golongan ini bernama Hukum Wadhi'i.

Adapun hukum Wadhi' $i$ terdapat tiga macam: ${ }^{6}$

1. Terdapat sebab, sebab adalah sesuatu yang tampak jelas dan tertentu menjadi tanda/pangkal adanya hukum, terdiri dari:

a. Sebab yang bukan hasil perbuatan manusia, misalnya peristiwa meninggalnya seseorang yang mengakibatkan harta peninggalnya beralih kepada ahli warisnya.

b. Sebab yang lahir dari perbuatan manusia, misalnya karena adanya akad nikah menjadi sebab adanya hubungan seks antara seorang pria dengan seorang wanita.

2. Tentang syarat, syarat adalah sesuatu yang padanya bergantung adanya sesuatu hukum yang berlaku, terdiri dari:

a. Syarat yang menyempurnakan sebab, misalnya jatuh tempo pembayaran zakat menjadi syarat untuk mengeluarkan zakat atas harta benda yang sudah mencapai jumlah tertentu untuk dikenakan zakat.

b. Syarat yang menyempurnakan sebab, misalnya berwudhu dan menghadap kiblat adalah menyempurnakan hakikat shalat.

c. Halangan (maani), maani adalah sesuatu yang karena adanya menghalangi berlakunya ketentuan hukum, terdiri dari:

1) Maani yang mempengaruhi sebab, misalnya ahli waris membunuh pewaris sehingga terhalang untuk menerima warisan.

2) Maani yang mempengaruhi akibat, misalnya ayah yang membunuh anaknya sendiri seharusnya dikenakan hukuman qisas, tetapi karena statusnya sebagai bapak menghalangi dijatuhkannya hukuman qisas.

\section{Prinsip-prinsip Hukum Islam}

Bersumber dari nilai ilahiyah diimplementasikan ke dalam sejumlah prinsip dasar atau asas yang lebih konkret dalam sejumlah bidang-bidang hukum Islam, yaitu: ${ }^{7}$

1. Prinsip Akidah yang tertuang ke dalam 5 rukun Islam dan 6 rukun Iman yang harus diterapkan oleh setiap muslim dalam kehidupannya. Sehingga pelakunya senantiasa dilandasi dengan akidah Islamiyah termasuk dalam aktivitas penegakan, kegiatan iqtishadiyyah (ekonomi), dan kegiatan politik, pendidikan, dan lainnya.

\footnotetext{
${ }^{5}$ Nasruddin Razak, 2001, Dienul Islam, Cetakan ke-20, Bandung, PT. Alma’arif, hlm.311

${ }^{6}$ M. Arfin Hamid, Op.Cit., hlm.16.

${ }^{7}$ Ibid., hlm. 22.
} 
2. Prinsip Ibadah yang dimaknakan secara luas bukan semata ibadah mahdlah (shalat, puasa, zakat, sedekah, haji, dll), melainkan juga meliputi aktivitas muamalah al-makhluqiyyah (hubungan interaksional ke seluruh makhluk) termasuk di dalamnya hubungan hukum, iqtishay (kegiatan bisnis), politik, budaya, pendidikan, keluarga, dan lainnya.

3. Prinsip Syariah (hukum), dengan prinsip ini menunjukkan segala aktivitas manusia senantiasa dikembalikan kepada ketentuan syariah sebagai dasar utamanya, sehingga kesyariahannya dapat terukur dan teruji.

4. Prinsip Tazkiyah (kesucian) yang mengandung makna sesungguhnya Allah itu Maha Suci dan hanya akan menerima yang suci pula, innallaha tayyibun Ia yaqbalu illa tayyiban.

5. Prinsip Khilafah (Kepemimpinan) yang terkandung di dalamnya sejumlah sifat nubuwwah seperti shiddiq (kejujuran), amanah (bertanggung jawab), fathonah (cerdas), tablieg (komunikatif/profesianal). Selain itu juga berlandaskan pada akhak, ukhuwah, dan insaniyah (humanistik), sehingga tidak terjadi eksploitasi antara satu dengan yang lainnya.

6. Prinsip Milkullah (pemilikan mutlak hanya ada ditangan Allah SWT), makna kepemilikan pada manusia hanya bersifat penguasaan/pengelolaan sebagai amanah dari Allah SWT, walillahi mulku assamawati wal ardhi (Pada Allahlah kepemilikan segala isi langit dan bumi).

7. Prinsip $A$ 'dalah (keadilan) didalamnya terbangun perilaku yang adil dalam menempatkan sesuatu secara proporsional, mengandung persamaan dan kebersamaan sebagai lawan dari kezhaliman, Ia tazhlimun wala tuzhlamun.

8. Prinsip Keseimbangan (al-Wustha) yang mengandung makna at-tawazhun suatu kemampuan dan sebagai tuntutan untuk senantiasa menyeimbangkan antara kepentingan dunia dan akhirat, kepentingan individu dan jamaah, antara lahiriyah dan bathiniah.

9. Prinsip Kemaslahatan (al-Maslahah) bahwa dalam menjalankan segala aktivitas dan usahanya pada intinya memberikan maslahat (skala prioritas), berupa kemanfaatan dan kegunaan kepada semua elemen dan di dalamnya tidak semaksimal mungkin menghindarkan kemudharatan bagi salah satu pihak termasuk juga pihak lainnya serta aman terhadap lingkungan.

Beberapa aplikasi asas/prinsip hukum Islam antara lain sebagai berikut: ${ }^{8}$

1. Tidak memberatkan dan tidak banyaknya beban;

Dengan prinsip ini menunjukkan bahwa ketentuan-ketentuan hukum Islam itu mudah dilaksanakan karena tidak banyak memberi beban sehingga tidak merepotkan, misalnya: Dalam hal Ibadat:

a. Sholat hanya diwajibkan dilakukan 5 (lima) kali sehari semalam;

b. Puasa hanya diwajibkan sebulan penuh dalam satu tahun;

c. Zakat hanya diwajibkan bagi orang yang mempunyai kelebihan harta benda dengan jumlah zakat, $10 \%, 5 \%$, atau $2 \frac{1}{2} \%$;

d. Menunaikan ibadah haji hanya diwajibkan sekali seumur hidup bagi mereka yang mampu.

Dalam lapangan muamalat terdapat pula ketentuan-ketentuan hukum yang meringankan, antara lain misalnya, dalam lapangan jual-beli sesungguhnya cukup dengan persetujuan belaka (bersifat konsensius).

${ }^{8}$ Mohammad Daud Ali, Op.Cit., hlm.114-128 
2. Penetapan hukumnya secara berangsur-angsur;

Hukum Islam tidak diturunkan sekaligus, tetapi secara berangsur-angsur. Al-Qur'an sebagai sumber pokok hukum Islam tidak diturunkan sekaligus dan lengkap, tetapi diturunkan secara berangsur-angsur, surah demi surah, Ayat demi Ayat dan atau peristiwa demi peristiwa, misalnya perbuatan minum arak dan main judi tidak sekaligus dilarang, melainkan pada awalnya hanya dikatakan, bahwa minum arak dan main judi adalah dosa akan tetapi disenangi oleh banyak orang. Jadi semula memang dilarang tetapi tidak secara tegas.

3. Sejalan dengan kebaikan orang banyak;

Hukum Islam ditetapkan oleh Allah dan Rasulnya untuk memenuhi kepentingan orang banyak seperti terdapat pada prinsip mendahulukan kepentingan umum di atas kepentingan pribadi dan golongan. Misalnya talak tiga yang diucapakan tanpa didahului dengan talak satu dan dua semula pada masa Rasul dan Khalifah Abu Bakar As Siddiq dianggap sebagai jatuh talak satu saja. Tetapi pada masa pemerintahan Khalifah Umar bin Khattab dirubah menjadi betul-betul jatuh talak tiga dan bukan talak satu. Hal tersebut ditetapkan demikian karena banyak laki-laki yang hanya main-main dengan ucapan itu. Apa yang ditentukan umar itu untuk melindungi kaum wanita dan memang sudah ditetapkan demikian, tidak ada laki-laki yang mempermainkan talak tiga itu.

4. Prinsip persamaan dan keadilan;

Syariat Islam tidak mengadakan diskriminasi antara orang yang satu dengan orang lainnya berdasarkan perbedaan warna kulit, status sosial, status ekonomi, dan sebagainya.

\section{Tujuan Hukum Islam}

Setiap peraturan mempunyai tujuan yang hendak dicapai oleh pembuatnya. Kalau kita meninjau tata aturan pada hukum positif maka tujuan pembuatannya tidak lain adalah ketentraman masyarakat, yaitu mengatur sebaik-baiknya dalam menentukan batas-batas hak dan kewajiban bagi setiap anggota masyarakat dalam hubungannya satu sama lain. Tujuantujuan yang bernilai tinggi dan abadi tidak menjadi perhatian aturan-aturan pada hukum positif kecuali hukum Islam yang sudah menjadi hukum positif.

Secara umum tujuan penciptaan dan penetapan hukum oleh Allah SWT adalah untuk kepentingan, kemaslahatan dan kebahagiaan manusia seluruhnya baik di dunia maupun di akhirat. Menurut Abu Zahra, terdapat tiga sasaran utama dari tujuan penetapan hukum Islam, yaitu pensucian jiwa, penegakan keadilan, da perwujudan kemaslahatan. ${ }^{9}$

Tujuan dari hukum Islam tidak terbatas dari segi material semata, tetapi jauh ke depan memperhatikan segala segi, material, immaterial, individu, masyarakat, dan kemanusiaan pada umumnya. Hal ini dapat dilihat pada segi ibadah dan muamalah, di samping itu untuk membersihkan jiwa dan taqarrub (mendekat) dengan Tuhannya, juga untuk kepentingan jasmani, serta kebaikan individu masyarakat dan kemanusiaan pada umumnya, dunia dan akhirat. Untuk mencapai tujuan tersebut, hukum Islam menentukan aturan yaitu menolak bahaya harus didahulukan daripada mengambil manfaat, kemaslahatan umum harus didahulukan dari kemaslahatan khusus, kesulitan akan dapat membawa kepada adanya

\footnotetext{
${ }^{9}$ Zainuddin Ali, Op.Cit, hal 10-11.
} 
kemudahan, keadaan darurat dapat memperbolehkan hal yang dilarang, tidak ada bahaya yang membahayakan, dan Islam tidak mengenal prinsip tujuan membenarkan cara. ${ }^{10}$

Sedangkan menurut Mohammad Daud Ali, tujuan hukum Islam dapat dilihat dari dua segi yaitu segi pembuat hukum Islam yakni Allah dan Rasul-Nya, dan dari segi manusia yang menjadi pelaku dan pelaksana hukum Islam itu: ${ }^{11}$

1. Segi pembuat hukum Islam, tujuan hukum Islam adalah:

a. Memenuhi keperluan hidup manusia yang bersifat primer (kebutuhan yang harus dilindungi dan dipelihara sebaik-baiknya agar kemaslahatan hidup manusia terwujud yang terdiri dari Agama, jiwa, akal, keturunan, dan harta), sekunder (kebutuhan yang dibutuhkan untuk mencapai kebutuhan primer seperti kemerdekaan dan persamaan), dan tersier (kebutuhan selain kebutuhan primer dan sekunder seperti sandang, pangan, dan papan);

b. Untuk ditaati dan dilaksanakan oleh manusia dalam kehidupan sehari-hari;

c. Agar ditaati dan dilaksanakan dengan baik dan benar, manusia wajib meningkatkan kemampuannya untuk memahami ushul fiqih (dasar pembentukan dan pemahaman hukum Islam sebagai metodeloginya).

2. Segi manusia menjadi pelaku dan pelaksana hukum Islam, tujuan hukum Islam adalah untuk mencapai kehidupan yang bahagia dan sejahtera dengan cara mengambil yang bermanfaat, mencegah dan menolak yang mudharat bagi kehidupan. Dalam hal kewarisan, tujuan sistem kewarisan Islam yang sesuai dengan tujuan hukum Islam adalah agar terhindar dari kesalahan dalam pembagian warisan yang dapat mengakibatkan pertikaian karena harta warisan dan terciptanya pembagian warisan yang adil serta diridhai Allah.

\section{Sumber-sumber Hukum Islam}

Sumber hukum Islam adalah asal (tempat pengambilan) hukum Islam. Dalam kepustakaan hukum Islam di tanah air kita, sumber hukum Islam kadang-kadang disebut dalil hukum Islam atau pokok hukum Islam atau dasar hukum Islam. ${ }^{12}$ Adapun sumber hukum Islam adalah Al-Qur'an, Al-Hadist, dan Ar-Ra'yu (penalaran). ${ }^{13}$ Dalam garis besarnya, sumber hukum Islam dibagi menjadi dua: ${ }^{14}$

1. Sumber Naqly, sumber hukum dimana seseorang mujtahid tidak mempunyai peranan dalam pembentukannya karena memang sumber hukum ini sudah tersedia. Yang termasuk dalam sumber hukum Naqly adalah Al-Qur'an, Hadist, Ijma, dan Urf atau adat.

a. Al-Qur'an adalah kumpulan wahyu ilahi yang disampaikan kepada nabi Muhammad SAW dengan perantara malaikat jibril untuk mengatur hidup dan kehidupan umat Islam pada khususnya dan umat manusia pada umumnya.

b. Hadist atau sunnah adalah segala apa yang datangnya dari Nabi Muhammad, baik berupa segala perkataan yang telah diucapkan, perbuatan yang pernah dilakukan pada masa hidupnya ataupun segala hal yang dibiarkan berlaku.

${ }^{10}$ A. Ma'mun Rauf, 1995, Hukum Islam: Asas-asas Hukum Islam, Cetakan kesepuluh, Makassar, Universitas Muslim Indonesia, hlm.133

${ }^{11}$ Mohammad Daud Ali, Op.Cit., hlm.61.

${ }^{12}$ Mohammad Daud Ali, Op.Cit, hlm.73 (dikutip dari: M.Tolchah Mansoer, 1980, 24; Mukhtar Yahya, $1979,21)$

${ }^{13}$ Zainuddin Ali, Op.Cit, hlm. 24.

${ }^{14}$ M. Arfin Hamid, Op.Cit, hlm.58. (dikutip dari Siraj, 1981: 74) 
c. Ijma adalah penyesuaian paham atau pendapat di antara para ulama mujtahid pada suatu masa tertentu untuk menentukan hukum suatu masalah yang belum ada ketentuan hukumnya.

d. Urf/adat atau kebiasaan adalah ketentuan-ketentuan hukum yang berasal dari kebiasaan masyarakat pra-Islam yang diterima oleh Islam karena tidak bertentangan dengan ketentuan-ketentuannya.

2. Sumber Aqly, sumber hukum di mana seorang mujtahid dapat berperan dalam pembentukannya. Misalnya Qiyas, Istihsan, dan istislah/muslahat-muslahah.

a. Qiyas adalah membandingkan atau mempersamakan atau menerapkan hukum dari suatu perkara yang sudah ada ketentuan hukumnya terhadap suatu perkara lain yang belum ada ketentuan hukumnya oleh karena kedua perkara yang bersangkutan mempunyai unsur-unsur kesamaan.

b. Istihsan adalah memindahkan atau mengecualikan hukum dari suatu peristiwa dari hukum peristiwa lain yang sejenis yang memberikan kepadanya hukum yang lain karena ada alasan yang kuat bagi pengecualian itu.

c. Istishlah atau muslahat-mursalah adalah menetapkan hukum dari sesuatu perkara berdasar pada adanya kepentingan umum atau kemuslahatan umat.

\section{KESIMPULAN}

Bahwa hukum Islam secara etimologis adalah segala macam ketentuan atau ketetapan mengenai sesuatu hal di mana ketentuan itu telah diatur dan ditetapkan oleh Agama Islam. Ruang lingkup hukum Islam dibagi menjadi dua antara lain 1) hukum yang berkaitan dengan persoalan ibadah, dan 2) hukum yang berkaitan dengan persoalan kemasyarakatan. Selain itu ada kajian tentang prinsip-prinsip hukum islam Bersumber dari nilai ilahiyah diimplementasikan ke dalam sejumlah prinsip dasar atau asas yang lebih konkret dalam sejumlah bidang-bidang hukum Islam. Serta Tujuan dari hukum Islam tidak terbatas dari segi material semata, tetapi jauh ke depan memperhatikan segala segi, material, immaterial, individu, masyarakat, dan kemanusiaan pada umumnya. Yang terakhir tentang sumbersumber hukum Islam Adapun sumber hukum Islam adalah Al-Qur'an, Al-hadistt, dan Arra'yu (penalaran).

\section{DAFTAR PUSTAKA}

M. Arfin Hamid. 2008. Hukum Islam Prespektif Keindonesiaan: Sebuah Pengantar dalam Memahami Realitas Hukum Islam di Indonesia, Fakultas Hukum Universitas Hasanuddin.

Ma'mun Rauf, 1995, Hukum Islam: Asas-asas Hukum Islam, Cetakan kesepuluh, Makassar, Universitas Muslim Indonesia.

Mohammad Daud Ali, 2007, Hukum Islam, Pengantar Ilmu Hukum dan Tata Hukum Islam di Indonesia, PT. Rajagrafindo, Jakarta.

Nasruddin Razak, 2001, Dienul Islam, Cetakan ke-20, Bandung, PT. Alma'arif.

Zainuddin Ali, 2006, Hukum Islam, Pengantar Ilmu Hukum Islam di Indonesia, Jakarta, Sinar Grafika. 